\title{
Safety and efficacy of repeat thrombolytic treatment after acute myocardial infarction
}

\author{
Harvey D White, David B Cross, Barbara F Williams, Robin M Norris
}

\begin{abstract}
Thrombolytic treatment for acute myocardial infarction increases the risk of subsequent reocclusion of the infarct related artery. The efficacy and safety of repeat thrombolytic treatment was assessed in 31 patients treated with streptokinase $(n=13)$ or tissue plasminogen activator $(n=18)$ a median of five days (1-716) after the first infusion. The indication for readministration was prolonged chest pain with new ST segment elevation. Efficacy was assessed by infarct artery patency at angiography at a median of eight days after readministration in 22 patients and by non-invasive criteria in 23 patients (reperfusion was deemed to be likely if serum creatine kinase was not increased or reached a peak $<12$ hours after infarction). Angiography showed patency of $70 \%$ of the infarct arteries after readministration of streptokinase and of $75 \%$ after tissue plasminogen activator. The corresponding patency rates assessed noninvasively were $73 \%$ and $75 \%$. Reinfarction was prevented in nine (29\%) patients. Allergic reactions occurred in four of eight patients who received streptokinase twice (plasmacytosis and acute reversible renal failure developed in one patient). Two patients had major bleeding and two minor bleeding, all after tissue plasminogen activator, and one of them died of cerebral haemorrhage.
\end{abstract}

Repeat thrombolytic treatment results in late patency rates similar to the rates after the initial administration. Allergic reactions were common in those treated twice with streptokinase.

Thrombolysis is now used widely in acute myocardial infarction to reduce mortality ${ }^{1-4}$ and to preserve left ventricular function. ${ }^{5}$ Thrombolysis of a coronary thrombus, however, results in an infarct related coronary artery with an unstable endothelial lesion and often residual thrombus. Angiographic studies showed a rate of about $20 \%$ for early reocclusion after thrombolysis. ${ }^{6}$ Reinfarction is associated with further tnyocardial damage and mortality. Though angioplasty seemed to be an attractive approach to preventing reocclusion, four studies showed no reduction of reinfarction..$^{7-10}$ Aspirin treatment has been clearly shown to reduce reinfarction but even so reinfarction occurs in approximately $2 \%$ of patients. $^{2}$ Another approach is to repeat thrombolytic treatment, either with the same or a different agent, if acute coronary thrombosis recurs.

The benefits of repeat thrombolytic treatment for threatened reinfarction may resemble those of the initial administration, but the risks and benefits have not been well described. We report the results of repeat thrombolytic treatment in 31 patients with threatened reinfarction.

\section{Patients and methods}

We studied 31 patients (22 men and nine women, mean (SD) age 58 (9) years) who had all been treated with intravenous thrombolysis for acute myocardial infarction. Indications for initial thrombolysis included ischaemic chest pain lasting more than 30 minutes with onset less than six hours before thrombolytic treatment and associated ST segment elevation of $\geqslant 1 \mathrm{~mm}$ in two limb leads or V4-V6 or $\geqslant 2 \mathrm{~mm}$ in leads $\mathrm{V} 1-\mathrm{V} 3$. The initial thrombolytic treatment was an infusion of streptokinase 1.5 million units intravenously over 30 minutes in 23 patients and of recombinant tissue plasminogen activator $100 \mathrm{mg}$ intravenously over three hours in eight patients. In all patients treatment with aspirin (50-300 mg per day) was started on admission to the coronary care unit and 12 patients were also given dipyridamole ( $400 \mathrm{mg}$ daily). Heparin was given intravenously for at least 48 hours in 19 patients, with dose adjustment to maintain the activated partial thromboplastin time between 90 and 110 seconds. Treatment with oral $\beta$ blockers was started within three days of admission in patients without contraindications. One patient underwent angioplasty of a severe stenosis of the left anterior descending coronary artery seven days after initial thrombolysis and three days before readministration.

\section{STUDY PROTOCOL}

Thrombolysis was repeated in patients in whom recurrent ischaemic pain lasting $>30$ minutes developed despite nitrate treatment and who fulfilled the criteria for ST segment elevation described above. Patients were given the same dose of either streptokinase or tissue plasminogen activator as was used for the initial treatment. All patients were treated by thrombolysis within six hours of the onset of the second episode of pain. The physician chose the thrombolytic agent; though strep-

\author{
Green Lane Hospital \\ Auckland 3, New Zealand. \\ Accepted for publication \\ 14 April 1990 \\ Auckland, \\ H D White \\ B F Williams \\ Correspondence to \\ Dr Harvey D White,
}


tokinase was generally avoided between seven days and three months after initial streptokinase treatment and in patients with allergic reactions to their first dose of streptokinase. Steroids or antihistamines were not routinely administered before repeat streptokinase treatment, but one patient did receive intravenous hydrocortisone before readministration. Concomitant treatment was similar to that during the initial administration; all patients were given aspirin and most were given intravenous heparin.

All patients were observed closely for evidence of allergic reactions or hypotension, and any bleeding was noted. Serum concentrations of creatine kinase were measured at least every four hours for the first 24 hours. Coronary arteriography was performed in survivors unless the coronary anatomy had already been defined. Coronary arteriography and left ventriculography were performed by the Judkins technique. The infarct related artery was identified by correlation of the coronary arteriogram with the electrocardiogram and wall motion abnormalities on biplane left ventriculography. The coronary arteries were viewed in multiple projections. The patency of the infarct related artery was coded according to the TIMI criteria. ${ }^{11}$

The time course of creatine kinase release from the onset of thrombolytic treatment was used as a non-invasive marker of early reperfusion. Patients with either no increase in serum creatine kinase or with an early peak of creatine kinase after thrombolytic treatment $(<9$ or $<12$ hours) were considered likely to have achieved reperfusion, ${ }^{12}$ though we have no independent validation of the specificity or sensitivity of these indices.

We excluded from the enzyme analysis patients in whom sampling was inadequate for reliable timing of the enzyme peak. We also excluded patients in whom persistence of raised creatine kinase concentrations after the index infarction made it difficult to time a "hump" on the washout curve.

\section{Results}

Table 1 shows the baseline characteristics of the study group. The threatened reinfarctions occurred at a median of 5 (range 1-716) days after the initial infarction. Table 2 shows the drug treatment that patients were receiving immediately before threatened reinfarction. All but two patients were taking aspirin and six patients were still receiving intravenous heparin after the initial thrombolytic treatment. The electrocardiographic changes associated with the threatened reinfarction were in the same coronary artery distribution as initial infarction in all but one patient.

The thrombolytic agent chosen for the repeat treatment was streptokinase in 13 patients and tissue plasminogen activator in 18 . The mean (SD) delay from the onset of pain to readministration was 107 (63) minutes. Eight patients received streptokinase on both occasions. Table 3 outlines the treatment given to each patient, the delay between initial
Table 1 Baseline characteristics of the study group

\begin{tabular}{lrc}
\hline Mean (SD) age (yr) & 58 & $(9)$ \\
Sex: & 22 & $(71 \%)$ \\
$\quad$ Male & 9 & $(29 \%)$ \\
$\quad$ Female & & \\
Site of initial infarct: & 9 & $(29 \%)$ \\
$\quad$ Anterior & 22 & $(71 \%)$ \\
$\quad$ Inferior & 23 & $(74 \%)$ \\
Initial thrombolytic agent: & 8 & $(26 \%)$ \\
$\quad$ Streptokinase & 19 & $(61 \%)$ \\
$\quad$ Tissue plasminogen activator & 18 & $(58 \%)$ \\
Angina before initial infarct & 8 & $(26 \%)$ \\
Angina after initial infarct and before & 14 & $(45 \%)$ \\
$\quad$ threatened reinfarction & 3 & $(10 \%)$ \\
Hypertension & & \\
Smoking & &
\end{tabular}

$\star$ Angina for $>48$ hours before initial thrombolytic treatment.

thrombolytic treatment and readministration, and the results of enzyme analysis and cardiac catheterisation.

Sampling for creatine kinase was adequate in 23 patients. One patient underwent an emergency operation for stenosis of the left main coronary artery and another underwent "rescue" angioplasty 2.5 hours after repeat thrombolysis. In five patients not enough samples were taken between six and 18 hours after readministration to determine the time of peak creatine kinase, and in one patient (case 9) in whom thrombolysis was repeated two days after the initial treatment, creatine kinase was still increased by the initial infarct.

Cardiac catheterisation was performed in 22 patients at a median of eight (0-63) days after repeat thrombolysis. Four patients had died, in four the coronary anatomy was already known, and in one elderly patient without inducible angina at exercise testing the physician wanted to avoid catheterisation.

\section{EFFICACY}

Table 4 summarises the results of non-invasive assessment of reperfusion and the angiographic assessment of infarct artery patency for the four possible combinations of thrombolytic treatment. Streptokinase achieved late angiographic patency in $70 \%$ of patients and tissue plasminogen activator achieved it in $75 \%$. In patients previously treated with streptokinase, readministration with either streptokinase or tissue plasminogen activator resulted in similar rates of reperfusion assessed non-invasively or angiographically. In nine $(29 \%)$ patients no rise in cardiac enzymes ensued, implying prevention of further myocardial necrosis.

Reperfusion assessed non-invasively and patency at late angiography were not always concordant. Both angiographic and enzyme data were available in 18 patients. Three $(23 \%)$

Table 2 Drug treatment at time of threatened reinfarction

\begin{tabular}{lr}
\hline Drug & No $(\%)$ \\
\hline Aspirin & $29(94)$ \\
Dipyridamole & $12(39)$ \\
Intravenous heparin & $6(19)$ \\
Subcutaneous heparin & $3(10)$ \\
$\beta$ Blockers & $18(58)$ \\
Calcium antagonists & $5(16)$ \\
Nitrates & $8(26)$ \\
\hline
\end{tabular}

${ }^{\star}$ Regular oral, sublingual or transdermal, or intravenous infusion. 
Table 3 Treatment and outcome of individual patients

\begin{tabular}{|c|c|c|c|c|c|c|c|c|c|c|}
\hline Patient & Agent 1 & Agent 2 & $\begin{array}{l}\text { Age } \\
(y r)\end{array}$ & Sex & $\begin{array}{l}\text { Interval } \\
\text { (days) }\end{array}$ & $\begin{array}{l}\text { Antithrombotic } \\
\text { treatment }\end{array}$ & $\begin{array}{l}\text { Peak CK on } \\
\text { readministration } \\
(U / l)\end{array}$ & $\begin{array}{l}\text { Hours } \\
\text { to peak }\end{array}$ & $\begin{array}{l}\text { Angiographic } \\
\text { patency of } \\
\text { infarct artery }\end{array}$ & Comments \\
\hline $\begin{array}{l}1 \\
2 \\
3 \\
4 \\
5 \\
5 \\
6 \\
7 \\
8\end{array}$ & $\begin{array}{l}\text { SK } \\
\text { SK } \\
\text { SK } \\
\text { SK } \\
\text { SK } \\
\text { SK } \\
\text { SK } \\
\text { SK }\end{array}$ & $\begin{array}{l}\text { SK } \\
\text { SK } \\
\text { SK } \\
\text { SK } \\
\text { SK } \\
\text { SK } \\
\text { SK } \\
\text { SK }\end{array}$ & $\begin{array}{l}59 \\
52 \\
65 \\
62 \\
43 \\
49 \\
49 \\
71\end{array}$ & $\begin{array}{l}\mathbf{M} \\
\mathbf{F} \\
\mathbf{M} \\
\mathbf{F} \\
\mathbf{M} \\
\mathbf{M} \\
\mathbf{M} \\
\mathbf{F}\end{array}$ & $\begin{array}{r}2 \\
3 \\
3 \\
5 \\
7 \\
8 \\
190 \\
268\end{array}$ & $\begin{array}{l}\text { ASP, DP, HEP } \\
\text { ASP } \\
\text { ASP, DP } \\
\text { ASP } \\
\text { ASP, DP } \\
\text { ASP, DP } \\
\text { ASP } \\
-\end{array}$ & $\begin{array}{c}\text { No rise } \\
484 \\
\text { No rise } \\
873 \\
418 \\
878 \\
369 \\
1856\end{array}$ & $\begin{array}{l}\overline{9} \\
\frac{-}{\star} \\
24 \cdot 5 \\
21 \\
{ }_{5}\end{array}$ & $\begin{array}{l}\text { Yes } \\
\text { Yes } \\
\text { Yes } \\
\text { Yes } \\
\text { Yes } \\
\text { No } \\
\text { No angiogram } \\
\text { No angiogram }\end{array}$ & $\begin{array}{l}\text { Allergic reaction } \\
\text { Allergic reaction } \\
\text { Allergic reaction } \\
\text { Allergic reaction } \\
\text { Sudden death } 47 \text { days }\end{array}$ \\
\hline 9 & SK & rt-PA & 49 & $\mathbf{M}$ & 2 & ASP, HEP & - & - & Yes & $\begin{array}{l}\text { Enzymes still raised after } \\
1 \text { st infarct }\end{array}$ \\
\hline $\begin{array}{l}10 \\
11 \\
12 \\
13 \\
14 \\
15 \\
16 \\
17\end{array}$ & $\begin{array}{l}\text { SK } \\
\text { SK } \\
\text { SK } \\
\text { SK } \\
\text { SK } \\
\text { SK } \\
\text { SK } \\
\text { SK }\end{array}$ & $\begin{array}{l}\text { rt-PA } \\
\text { rt-PA } \\
\text { rt-PA } \\
\text { rt-PA } \\
\text { rt-PA } \\
\text { rt-PA } \\
\text { rt-PA } \\
\text { rt-PA }\end{array}$ & $\begin{array}{l}59 \\
71 \\
55 \\
56 \\
68 \\
47 \\
48 \\
62\end{array}$ & $\begin{array}{l}M \\
M \\
M \\
M \\
F \\
M \\
M \\
\mathbf{F}\end{array}$ & $\begin{array}{l}2 \\
3 \\
3 \\
4 \\
5 \\
5 \\
5 \\
7\end{array}$ & $\begin{array}{l}\text { ASP } \\
\text { ASP, HEP } \\
\text { ASP } \\
\text { ASP } \\
\text { ASP } \\
\text { ASP } \\
\text { ASP } \\
\text { ASP, DP }\end{array}$ & $\begin{array}{l}974 \\
734 \\
\text { No rise } \\
\text { No rise } \\
\text { No rise } \\
846 \\
\text { No rise }\end{array}$ & $\begin{array}{l}\frac{13}{24} \\
\frac{-}{4.5} \\
-\end{array}$ & $\begin{array}{l}\text { No } \\
\text { No angiogram } \\
\text { Yes } \\
\text { Yes } \\
\text { No angiogram } \\
\text { Yes } \\
\text { Yes } \\
\text { No angiogram }\end{array}$ & $\begin{array}{l}\text { Died-cerebellar } \\
\text { haemorrhage }\end{array}$ \\
\hline $\begin{array}{l}18 \\
19 \\
20 \\
21 \\
22 \\
23\end{array}$ & $\begin{array}{l}\text { SK } \\
\text { SK } \\
\text { SK } \\
\text { SK } \\
\text { SK } \\
\text { SK }\end{array}$ & $\begin{array}{l}\text { rt-PA } \\
\text { rt-PA } \\
\text { rt-PA } \\
\text { rt-PA } \\
\text { rt-PA } \\
\text { rt-PA }\end{array}$ & $\begin{array}{l}68 \\
66 \\
73 \\
47 \\
46 \\
48\end{array}$ & $\begin{array}{l}\mathbf{M} \\
\mathbf{F} \\
\mathbf{M} \\
\mathbf{M} \\
\mathbf{M}\end{array}$ & $\begin{array}{r}9 \\
11 \\
19 \\
23 \\
34 \\
716\end{array}$ & $\begin{array}{l}\text { ASP } \\
\text { ASP } \\
\text { ASP, HEP } \\
\text { ASP, DP } \\
\text { ASP, DP } \\
-\end{array}$ & $\begin{array}{c}5679 \\
1019 \\
794 \\
\text { No rise } \\
644 \\
7522\end{array}$ & $\begin{array}{l}\frac{17 \cdot 4}{\star 5} \\
\frac{5}{12} \\
8 \cdot 2\end{array}$ & $\begin{array}{l}\text { Yes } \\
\text { No angiogram } \\
\text { No angiogram } \\
\text { Yes } \\
\text { Yes } \\
\text { No }\end{array}$ & Died-stroke (embolic) \\
\hline $\begin{array}{l}24 \\
25 \\
26 \\
27 \\
28\end{array}$ & $\begin{array}{l}\text { rt-PA } \\
\text { rt-PA } \\
\text { rt-PA } \\
\text { rt-PA } \\
\text { rt-PA }\end{array}$ & $\begin{array}{l}\text { SK } \\
\text { SK } \\
\text { SK } \\
\text { SK } \\
\text { SK }\end{array}$ & $\begin{array}{l}51 \\
57 \\
59 \\
66 \\
43\end{array}$ & $\begin{array}{l}\mathrm{M} \\
\mathrm{F} \\
\mathbf{M} \\
\mathbf{M}\end{array}$ & $\begin{array}{r}1 \\
2 \\
3 \\
9 \\
169\end{array}$ & $\begin{array}{l}\text { ASP, DP, HEP } \\
\text { ASP } \\
\text { ASP, DP } \\
\text { ASP } \\
\text { ASP, DP }\end{array}$ & $\begin{array}{l}948 \\
736 \\
\text { No rise } \\
.495 \\
504\end{array}$ & $\frac{\bar{\star}}{\overline{11} \cdot 7}$ & $\begin{array}{l}\text { No } \\
\text { Yes } \\
\text { No } \\
\text { Yes } \\
\text { No angiogram }\end{array}$ & $\begin{array}{l}\text { Early angioplasty } \\
\text { Allergic reaction } \\
\text { Allergic reaction }\end{array}$ \\
\hline $\begin{array}{l}29 \\
30\end{array}$ & $\begin{array}{l}\text { rt-PA } \\
\text { rt-PA }\end{array}$ & $\begin{array}{l}\text { rt-PA } \\
\text { rt-PA }\end{array}$ & $\begin{array}{l}60 \\
63\end{array}$ & $\underset{M}{F}$ & $\begin{array}{r}4 \\
12\end{array}$ & $\begin{array}{l}\text { ASP, DP } \\
\text { ASP, DP }\end{array}$ & $\begin{array}{l}\text { No rise } \\
584\end{array}$ & $\overline{12}$ & $\begin{array}{l}\text { No } \\
\text { Yes }\end{array}$ & $\begin{array}{l}\text { Bleeding venepuncture } \\
\text { site }\end{array}$ \\
\hline 31 & rt-PA & $\mathrm{rt}-\mathrm{PA}$ & 72 & $\mathbf{F}$ & 23 & ASP, HEP & 674 & 17 & No angiogram & $\begin{array}{l}\text { Died early-cardiogenic } \\
\text { shock }\end{array}$ \\
\hline
\end{tabular}

*Inadequate sampling.

SK, streptokinase; rt-PA, recombinant tissue plasminogen activator (alteplase); CK, creatine kinase (normal <300 U/1); ASP, aspirin; DP, dipyridamole; HEP, heparin.

of 13 patients in whom enzyme analysis suggested reperfusion subsequently had an occluded infarct artery, and three of the five patients in whom enzyme analysis did not support early reperfusion subsequently had a patent infarct artery.

\section{ADVERSE REACTIONS}

Allergic reactions were seen in four of the eight patients who received streptokinase on two occasions. The interval between the initial and second administrations was three days in two, five days in one, and seven days in another. The four patients who did not have an allergic reaction were retreated on days $2,8,190$, and 268. Allergic reactions were characterised by transient fever and rigors. No patients suffered bronchospasm, angio-oedema, or anaphylactic shock with readministration of streptokinase. In one patient plasmacytosis and transient renal impairment subsequently developed. ${ }^{13}$
No allergic reactions were seen with tissue plasminogen activator.

Transient hypotension and bradycardia were seen during thrombolytic infusion in five patients-two receiving streptokinase and three tissue plasminogen activator. All patients with significant hypotension had a threatened inferior infarction.

All important haemorrhagic complications were associated with treatment with tissue plasminogen activator. A 62 year old woman died after receiving tissue plasminogen activator for threatened reinfarction seven days after initial treatment with streptokinase. Neurological signs developed six hours after the start of treatment and necropsy showed a recent cerebellar haemorrhage. In a second patient a large groin haematoma developed at the site of arterial puncture after angioplasty three days earlier and required transfusion of 1.5 litres of blood. One patient had a single

Table 4 Patency and reperfusion rates after repeat thrombolytic treatment

\begin{tabular}{|c|c|c|c|c|c|c|}
\hline \multirow[b]{2}{*}{ Agent 1} & \multirow[b]{2}{*}{ Agent 2} & \multirow[b]{2}{*}{ No } & \multirow[b]{2}{*}{$\begin{array}{l}\text { Angiographic } \\
\text { patency }{ }^{\star}\end{array}$} & \multicolumn{3}{|c|}{ Reperfusion (enzymes) } \\
\hline & & & & No $C K$ rise & $\begin{array}{l}\text { Peak } C K<9 h \\
\text { or no } C K \text { riset }\end{array}$ & $\begin{array}{l}\text { Peak } C K<12 \mathrm{~h} \\
\text { or no } C K \text { rise }\end{array}$ \\
\hline $\begin{array}{l}\text { SK } \\
\text { SK } \\
\text { rt-PA } \\
\text { rt-PA } \\
\text { Total }\end{array}$ & $\begin{array}{l}\text { SK } \\
\text { rt-PA } \\
\text { rt-PA } \\
\text { SK }\end{array}$ & $\begin{array}{r}8 \\
15 \\
3 \\
5 \\
31\end{array}$ & $\begin{array}{l}5 / 6 \\
8 / 10 \\
1 / 2 \\
2 / 4 \\
16 / 22(73 \%)\end{array}$ & $\begin{array}{l}2 / 6 \\
5 / 12 \\
1 / 3 \\
1 / 2 \\
9 / 23(39 \%)\end{array}$ & $\begin{array}{l}4 / 6 \\
8 / 12 \\
1 / 3 \\
1 / 2 \\
14 / 23(61 \%)\end{array}$ & $\begin{array}{l}4 / 6 \\
9 / 12 \\
2 / 3 \\
2 / 2 \\
17 / 23(74 \%)\end{array}$ \\
\hline
\end{tabular}

^Patency $=$ TIMI 2 or 3 flow.

†Time from start of thrombolytic treatment.

SK, streptokinase; rt-PA, recombinant tissue plasminogen activator (alteplase); CK, creatine kinase. 
episode of macroscopic haematuria and another experienced prolonged skin bleeding from venepuncture sites.

Three patients died within 30 days of readministration of thrombolytic treatment. One patient died from cerebellar haemorrhage as outlined above, one of an embolic stroke 12 days after readministration, and another of cardiogenic shock 24 hours after readministration. One further patient died suddenly 47 days after threatened reinfarction.

\section{ANGIOPLASTY AND OPERATION}

Angioplasty was performed electively within three days of repeat thrombolytic treatment in nine patients. Two further patients had reinfarctions while awaiting intervention; one proceeded to angioplasty and one to urgent coronary surgery. Five other patients subsequently underwent coronary artery surgery. Eleven survivors were initially managed conservatively, but two subsequently required angioplasty for severe angina and one had a late reinfarction.

\section{Discussion}

Reinfarction occurs in approximately $9 \%$ of patients during the first 12 months after thrombolytic treatment for acute infarction. ${ }^{14}$ It is attractive to extrapolate the substantial evidence for benefit seen with initial use of thrombolytic treatment to readministration in the event of subsequent threatened infarction, but the risks and benefits of this approach are not well defined.

Streptokinase is a foreign protein and is antigenic in humans. Possible allergic reactions were reported in $4.4 \%$ of patients treated with streptokinase in ISIS $-2^{2}$ and $3.4 \%$ of patients receiving streptokinase in GISSI-1. ${ }^{1}$ Anaphylactic shock occurred in $0.1 \%$ of patients treated with streptokinase in GISSI- ${ }^{1}$ and did not occur in ISIS-2. ${ }^{2}$ The use of prophylactic steroids is theoretically unlikely to be helpful. ${ }^{15}$ In ISIS-2 $22 \%$ of patients received prophylactic steroids, with no reduction in the reported rate of allergic reaction.

Because most patients already have antibodies to streptokinase from previous streptococcal infections the dose needs to be greater than 1.25 million units to ensure that these antibodies are overcome. ${ }^{16}$ Neutralising antibodies sufficient to inhibit conventional doses of streptokinase develop as early as four days after administration. This titre of antibody persists in most patients tested at six months and one year ${ }^{17}$ (and D Massell, JB Gill, AGG Turpie, JA Cairns, personal communication). The relation between lytic efficacy and antibody titres is not clear. Moran et al found a discrepancy between streptokinase specific IgG measured by a radioimmunoassay technique and the functional streptokinase resistance titre in some patients. ${ }^{18}$. Even so, it seems prudent to avoid readministration of streptokinase when antibody titres are likely to be high. The presence of IgE antibodies is likely to increase the risk of immediate allergic reactions, and high IgG titres (in addition to compromising efficacy) may increase the risk of late complications such as serum sickness and Guillain-Barré syndrome, which are occasionally seen after initial treatment. ${ }^{19-22}$ It has been suggested that streptokinase resistance titres should be measured before streptokinase is readministered, and the dose increased appropriately. ${ }^{23}$ We think that such an approach is untenable because it would delay thrombolytic treatment.

Because anistreplase contains streptokinase a similar incidence of hypersensitivity reactions might be expected. In the German multicentre trial $2.5 \%$ of patients receiving anistreplase had allergic reactions ${ }^{24}$ and 'two of 502 patients receiving anistreplase in the AIMS Study suffered anaphylactic reactions. ${ }^{4}$ Vasculitis has also been reported after treatment with anistreplase. $^{25}$

Readministration of plasminogen activators such as tissue plasminogen activator and urokinase, which are non-allergenic, is less likely to reduce efficacy and cause allergic reactions. Little is known of the risks of readministration of these agents, however, particularly of haemorrhage during the first few days after initial treatment. These agents are also more expensive than streptokinase.

This study shows that repeat thrombolysis was feasible and was as effective in restoring vessel patency and probably in limiting myocardial necrosis as the initial treatment. Efficacy was assessed by two methods. Patency of a coronary artery late after thrombolytic treatment does not necessarily indicate early patency. We found a similar high frequency of early reperfusion assessed by enzyme analysis and late arteriographic patency, but as expected there were some discrepancies. In nearly a third of patients receiving repeat thrombolytic treatment for prolonged chest pain with ST segment elevation there was no elevation of cardiac enzymes. We believe that reinfarction was prevented in these patients.

Allergic reactions were frequent when streptokinase was given twice, but these reactions were not associated with a lack of lytic efficacy. Transient hypotension was equally common during the initial and repeat infusions and was not confined to streptokinase treatment.

The role of angioplasty and coronary surgery after readministration of thrombolysis is uncertain. Trials of early angioplasty after initial thrombolysis $^{7-9}$ and comparison of conservative and invasive management strategies ${ }^{1026}$ suggest that watchful waiting is better than immediate intervention in most patients. These results clearly cannot be extrapolated to patients with threatened reinfarction. We have often offered such patients a revascularisation procedure on the assumption that a patient suffering two acute coronary events is more likely to have a third. There is no firm evidence for this approach and prospective clinical trials are required.

We believe that prompt readministration of thrombolytic treatment is appropriate in patients with threatened reinfarction and is likely to be as safe and effective as the initial treatment. In view of concerns about efficacy 
and the occurrence of allergic reactions, we think that streptokinase or anistreplase should not be readministered within a year. We need more information on how common high antistreptokinase titres are more than one year after the initial treatment.

We thank the nurses and physicians who treated the patients in this study.

This study was supported in part by grants from the New Zealand Medical Research Council and the National Heart Foundation of New Zealand.

1 Gruppo Italiano per lo Studio Della Streptochinasi nell' Infarto Miocardico (GISSI). Effectiveness of intravenous thrombolytic treatment. in acute myocardial infarction. thrombolytic treatment.

2 ISIS-2 (Second International Study of Infarct Survival) Collaborative Group. Randomised trial of intravenous streptokinase, oral aspirin, both, or neither among 17187 cases of suspected acute myocardial infarction: ISIS-2. Lancet 1988;i1:349-60.

3 Wilcox RG, Von der Lippe G, Olsson CG, et al. Trial of tissue plasminogen activator for mortality reduction in acute myocardial infarction. Anglo-Scandinavian Study of Early Thrombolysis (ASSET). Lancet 1988;ii:525-30.

4 AIMS Trial Study Group. Effect of intravenous APSAC on mortality after acute myocardial infarction: preliminary i: $545-9$.

5 White HD, Norris RM, Brown MA, et al. Effect of intravenous streptokinase on left ventricular function and early survival after acute myocardial infarction. $N$ Engl $J$ Med 1987;317:850-5.

6 Schaer DH, Ross AM, Wasserman AG. Reinfarction, recurrent angina, and reocclusion after thrombolytic current angina, and reocclusion after th

7 The TIMI Research Group. Immediate vs delayed catheterization and angioplasty following thrombolytic therapy for acute myocardial infarction. TIMI 11A results. JAMA 1988;260:2849-58.

8 Topol EJ, Califf RM, George BS, et al, and the Thrombolysis and Angioplasty in Myocardial Infarction Study Group. A randomized trial of immediate versus delayed elective angioplasty after intravenous tissue plasminogen
activator in acute myocardial infarction. $N \mathrm{Engl} \mathrm{J} \mathrm{Med}$ 1987;317:581-8.

9 Simoons ML, Arnold AER, Betriu A, et al for the European Co-operative Study Group for Recombinant Tissue-type Plasminogen Activator. Thrombolysis with tissue plasminogen activator in acute myocardial infarction: no minogen activator in acute myocardial infarction: no additional benefit from immediate per

10 The TIMI Study Group. Comparison of invasive and conservative strategies after treatment with intravenous tissue plasminogen activator in acute myocardial infarction. N Engl J Med 1989;320:618-27.

11 The TIMI Study Group. The thrombolysis in myocardial infarction (TIMI) Trial: Phase I findings. $N$ Engl J Med 1985;312:932-6.

12 Schroeder R, Biamino G, von Leitner ER, et al. Intravenous short-term infusion of streptokinase in acute myocardial infarction. Circulation 1983;67:536-48.

13 Chan NS, White H, Maslowski A, Cleland J. Peripheral plasmacytosis and renal failure after readministration of streptokinase following myocardial infarction. $\mathrm{Br}$ Med $\mathrm{J}$ 1988;297:717-8.

14 Rivers JT, White HD, Cross DB, Williams BF, Norris RM. Reinfarction after thrombolytic therapy for acute myocardial infarction followed by conservative management: incidence and effect of smoking. J Am Coll Cardiol (in press).

15 McGrath KS, Patterson R. Anaphylactic reactivity to streptokinase. JAMA 1984;252:1314-7.

16 Verstraete M, Vermylen J, Amery A, Vermylen C. Thrombolytic therapy with streptokinase using a standard dosage bolytic therapy with streptokinase

17 Massel D, Turpie AGG, Gill JB, Cairns JA, Russett J. Development of neutralizing antibodies after 1.5 million units of streptokinase in the treatment of acute myocardial infarction [Âbstract]. Circulation 1989;80 (suppl II):350

18 Moran DM, Standring R, Lavender EA, Harris GS. Assessment of antistreptokinase antibody levels in human sera using a microradioimmunoassay procedure. Thromb Haemost 1984;52:281-7.

19 Weatherbee TC, Esterbrooks DJ, Katz DA, Aronow WS, Kenik JG, Mohiuddin SM. Serum sickness following selective intracoronary streptokinase. Curr Ther Res 1984; 35:433-8.

20 Davidson JR, Bush RK, Grogan EW, Boh LA, Graziano FM. Immunology of a serum sickness/vasculitis reaction secondary to streptokinase used for acute myocardial infarction. Clin Exp R heumatol 1988;6:381-4.

21 Eden KK. Possible association of Guillain-Barré syndrome with thrombolytic therapy. JAMA 1983;249:2020-1.

22 Leaf DA, MacDonald I, Kliks B, Wilson R, Jones SR Streptokinase and the Guillain-Barré syndrome. Ann Interm Med 1984:100:617.

23 Jalihal S, Morris GK. Antistreptokinase titres after intravenous streptokinase. Lancet 1990;335:184-5.

24 Meinert T, Kasper W, Schumacher M, Just H, for the APSAC Multicenter Trial Group. The German Multicenter Trial of anisoylated plasminogen streptokinase activator complex versus heparin for acute myocardia infarction. Am J Cardiol 1988;62:347-51.

25 Bucknall C, Darley C, Flax J, Vincent R, Chamberlain D. Vasculitis complicating treatment with intravenous anisoylated plasminogen streptokingse activator comous anisoylated plasminogen streptokinase activator complex

26 de Bono DP, Pocock SJ, for the SWIFT Investigators Group. The SWIFT study of intervention versus conservative management after Anistreplase thrombolysis [Abstract]. Circulation 1989;80 (suppl II):418. 